\title{
Research on the Role of Ideological and Political Education in Changing Undergraduates' Employment and Entrepreneurship
}

\author{
Dai Rui \\ Jinqiao College of Kunming University of Technology, Yunnan, China
}

Keywords: employment; entrepreneurship; college students; ideological and political education

\begin{abstract}
Digging and exerting the role of ideological and political education in the process of entrepreneurship and employment of college students is an inevitable requirement for strengthening and improving the ideological and political education of college students in the new situation, and it is also an objective need to promote the college students' employment. The paper analyzes the role of ideological and political education for entrepreneurial employment of college students from multiple dimensions: value leadership, ability development, shaping psychological quality, fostering professional ethics, and building campus culture. And from the perspective of the realization of the role of ideological and political education, it discusses issues that need attention in the process of its role.
\end{abstract}

\section{Introduction}

Ideological and political education plays an irreplaceable role in the employment and entrepreneurial process of college students through the correct employment outlook, entrepreneurial outlook education, psychological adjustment of employment and entrepreneurship, psychological intervention in employment and entrepreneurship frustration, basic humanistic quality of employment, and cultivation of the basic spiritual qualities of entrepreneurship. These aspects can be summed up mainly in the guidance of value-based guidance, professors based on facts, and guidance based on skills, so as to form a strong ideological support and promotion system for undergraduate employment and entrepreneurship, thus promoting the successful employment and active entrepreneurship of college students.

\section{Current Misconceptions Employment and Entrepreneurship}

\subsection{Emphasis is given to professional counterparts}

When many university graduates find jobs, they unconsciously emphasize the consistency of their majors and their work positions, and pursue a professional counterpart in employment. They believe that if they give up their specialties and choose other industries, they will not be able to engage in new jobs in the future. However, the real counterpart work does not exist in theory. With the development and progress of the society, the refinement of the work is getting deeper and deeper. The knowledge of the university is only related to the basic content of the major, which cannot be qualified for the present job requirements. In turn, some jobs do not necessarily require the professional knowledge of the University.

\subsection{Passive or resistant to employment}

The survey found that some students have a weak sense of active employment, and they rely on colleges and families to provide jobs or venture capital, and lack the enthusiasm of active employment and independent entrepreneurship. Some of these students have good family situations, and their parents are able to help students find jobs or provide entrepreneurial support. Some of them are poor in their overall quality, lack of independent awareness, lack of confidence in employment and venture, and dare not try. 


\subsection{Unclear self-positioning}

Through graduate surveys and analysis, it is found that graduates generally reflect a strong sense of frustration during the job search process, affecting the enthusiasm of the next job search. The frustration of the graduates is mainly due to the lack of self-awareness in the career planning, the unrealistic position of the job hunting position, the frequent encounter in the job search, and the combination of comparison and vanity, which is not conducive to the physical and mental health of the graduates and the smooth employment and entrepreneurship.

\section{The Role of Ideological and Political Education in Changing the Concept of Employment and Entrepreneurship}

\subsection{Promote college students to establish correct world outlook, outlook on life and values}

Through ideological and political education, college students can be guided in career planning education, self-understanding, understanding of society, and combining personal interests, hobbies and strengths with the needs of the country, society, and industry, and establishing a correct world outlook, outlook on life, and values. The employment situation and policy education for college students can make students understand the current employment situation, especially the present situation of the major and the industry, change the thinking of blind optimism and negative pessimistic employment, analyze the situation, make a reasonable position, and know oneself and the other when looking for a job, so that they can win in the fierce competition of employment.

\subsection{Promote college students to establish good professional ethics}

Through ideological and political education, building a good faith campus atmosphere, establishing the daily faith archives and so on to strengthen the integrity education, let the students realize the importance of honesty and credit, and promote the honesty of the students. Through the holding of social practice activities, compulsory labor and other activities, training college students' dedication, and then combining ideological and political education case teaching, let students deeply understand the importance of dedication, start from self and start from small things, gradually improve college students to contribute to social awareness. Through practice of the activities of the socialist core values, training students' sense of responsibility and the spirit of ownership, to overcome the self - selfish bad style and to work with a strong sense of responsibility.

\subsection{Promote college students' comprehensive quality and employment competitiveness}

To solve the contradiction between the supply and demand of graduates, in addition to guiding graduates to change the concept of employment, but also through the school education to strengthen the overall quality and competitiveness of graduates. First of all, through ideological and political education to help students change roles in internship activities, quickly adapt to social needs, adapt to the working environment, and quickly enter working conditions. Secondly, it should establish the long-term mechanism of practice education under the new situation, actively explore and establish the learning mechanism of social practice, professional study, social service and community activities, strengthen the students' professional experience through various forms of practical activities, improve the students' social adaptability, and thus improve their employment competitiveness.

\subsection{Promote college students to cultivate entrepreneurial awareness}

Ideological and political education as the "main battlefield" of students' ideological education also plays an important role in cultivating the entrepreneurial awareness of college students and stimulating students' entrepreneurial enthusiasm. First of all, the cultivation of entrepreneurial awareness is listed as one of the ideological and political education curriculum content, infiltrate the concept of entrepreneurship and entrepreneurial thinking, and gradually establish entrepreneurial ideals and beliefs. Secondly, through successful entrepreneurial case studies, students are encouraged to set up entrepreneurial role models and stimulate their entrepreneurial passion. Thirdly, in the teaching process, students' subjective initiative should be brought into full play to inspire students to 
study independently, think independently, and be free to innovate, change passive acceptance as active participation, and motivate students' innovative learning. Fourth, in the teaching of ideological and political courses, it should publicize relevant systems and policies for entrepreneurship in the country, provinces, cities, and colleges, to encourage students to actively participate in entrepreneurship, and increase entrepreneurial confidence.

\section{Ways to Change Employment and Entrepreneurial Concepts through Ideological and Political Education}

The concept of employment and entrepreneurship of college students is an ideological issue. It is not that easy to change and requires all sectors of society, and especially colleges should to pool all relevant forces together. In terms of colleges, it should optimize and integrate ideological and political education resources and other humanities educational resources to accomplish the task.

\subsection{Realize the optimization and integration of human resources in ideological and political education}

Ideological and political education is a macro system, and its implementation includes the following different levels, as showed in table 1.

Table 1. Implementation levels

\begin{tabular}{ll}
\hline Levels & Contents \\
\hline Ideological and political teacher & They play a major role in student ideological education. \\
Administrators & They are the guides and regulators of ideological education. \\
Counselor & They are direct contact with students' daily learning and life. \\
& $\begin{array}{l}\text { They are trainers of employment entrepreneurship knowledge } \\
\text { Career guidance teachers }\end{array}$ \\
& $\begin{array}{l}\text { They are the direct influencers of students' personal choice, or } \\
\text { Citizens }\end{array}$ \\
\hline
\end{tabular}

Comprehensively integrating the above five resources, we can smoothly realize the ideological and political education of college students and play a positive guiding role in changing students' employment and entrepreneurial concepts.

\subsection{Realize the organic combination of ideological and political education and other humanities education}

The humanities education in Colleges and universities is an organic whole. There are usually close links between various disciplines. Both the contents and functions are very similar. Therefore, in order to achieve a specific educational effect, we usually have to establish a connection between disciplines and realize the organic combination of the relevant disciplines. Firstly is to realize the organic integration of ideological and political education and mental health education. Although ideological and political education and mental health education are different in content, methods and emphasis, there is an inevitable connection in the education of people, which is mainly reflected in the following aspects, as showed in table 2.

The combination of ideological and political education and mental health education, which complement each other, can greatly enhance the effectiveness of university education and can further improve the quality of employment and entrepreneurship education for university graduates. It plays an important role in transforming college students' employment and entrepreneurship concepts.

Second is to realize the organic integration of ideological and political education and career planning education. Both ideological and political education and career planning education are humanized education, and both emphasize practicality. Theoretical teaching, practice training, model education, self-analysis, and personalization analysis are fully reflected in both educations. It is to promote the healthy growth of college students and improve their ideological understanding so that 
they can actively participate in society and realize their self-worth and social values.

Table 2. Ideological \& political education and mental health education connections

\begin{tabular}{ll}
\hline Items & Contents \\
\hline & Mental health education focuses on the psychological level. \\
Complementarity of educational & $\begin{array}{l}\text { The core issue is to solve the growth problem. The } \\
\text { ideological and political education focuses on the } \\
\text { content }\end{array}$ \\
& ideological level. The core issue is the solution to the \\
outlook on life, world outlook, and values.
\end{tabular}

Consistency of educational goals They are all solutions to human ideology.

Mutual precondition in the work They are interrelated and promoted each other in the actual of educating people execution process.

And last is to realize the organic combination of ideological and political education and the innovation of entrepreneurship education, one of the core functions of ideological and political education is to motivate the people's spiritual motivation. Through ideological and political education, it can stimulate the vitality and creativity of the people, which is one of the aims of innovation and entrepreneurship education. Therefore, it can say that the this two aspects can be interconnected and interacted in the educational function.

\section{Conclusion}

In transforming the concept of employment and entrepreneurship of graduates, colleges and universities should give full play to the leading role of ideological and political education, integrate the existing educational resources of schools and society, and provide ideological and political education, psychological education, career planning education, and innovation and entrepreneurship education to college students to help them change the concept of employment and entrepreneurship, and promote the employment of high quality college students.

\section{References}

[1] Liu Bingbing, Liu Ruowang. Investigation and analysis of the undergraduates' business viewpoint[J]. Higher Education Research, 2009(2): 81-83.

[2] Liu Zhaoping. Combination of ideological and political education and entrepreneurship education for college students[J]. Journal of Nantong University, 2007 (3): 79-80.

[3] Shen Hongyu. Culture of entrepreneurial talents and ideological and political education of university students[J]. Journal of Northeast Agricultural University, 2004(3): 7-8.

[4] Wang Lingyu. Suggestions on promoting university graduates' self-employment[J]. Education and Society, 2009(3): 21-22. 